\title{
The British Society in the 1980s and the 1990s Reflected in the Poems of Carol Ann Duffy
}

\author{
Xiaohong Sheng \\ School of Foreign Language \\ East China Jiaotong University \\ Nanchang, Jiangxi, China \\ E-mail: echoshengbfsu@sina.com
}

Keywords: Carol Ann Duffy; British society in the 1980s and 1990s; moneymaking; aimlessness; racial intolerance

\begin{abstract}
As the first Scottish and first woman to be appointed as Britain's Poet Laureate, Carol Ann Duffy, by using the weapon of poetry, addresses a wide range of issues related to her people and her gender, including social, economic and gender oppressions confronted with by the working class of Britain. This paper, by analyzing the social situations of Britain in the 1980s and 1990s under the administration of Margaret Thatcher, studies Carol Ann Duffy's poems, mainly those from the three collections Selling Manhattan, Standing Female Nude and The Other Country, from the perspective of their reflection of the then British society. It studies in detail Duffy's poems and reveals three main aspects of the British society in the Thatcherite world: commercialism and moneymaking elevated as the top notion of people, selfishness and aimlessness among the young generation along with the state of despair and severe unemployment, and racial and cultural intolerance in the multicultural Britain.
\end{abstract}

\section{Introduction}

Widely acknowledged as a feminist poet, Carol Ann Duffy has gained great fame for her concern with gender issues in poetry collections like The World's Wife and The Famine Gospels. As Rees Jones remarks, "Do we read her as a Scottish poet? A Scottish woman poet? A feminist poet? A working-class poet? Is she a political poet, dramatic poet, or a lyric poet? Of course, she is all of these things and none of them (Ree-Jones 5)". Nevertheless, Duff's poetry, closely related to the British society of the 1980s and 1990s, is political as well and provides a panoramic view of Thatcherite Britain. Her works Standing Female Nude, Selling Manhattan, Mean Time, and especially The Other Country touch not only topics like love, nostalgia and childhood, but reflect life in contemporary Britain under Margaret Thatcher's administration. By giving voice to the marginalized, the immigrant, the unemployed, Duffy acidly criticizes the "go-getting, me-first, thrusting Thatcherite world of 1980s values "(Driver and Martell 464) as well as its accompanied features which dominated the society like consumerism, money-making, racial intolerance and political indifference towards the underprivileged.

Opening with a brief introduction of the British society in 1980s and 1990s, this paper focuses on some selected poems from Duff's poetry collections, Standing Female Nude, Selling Manhattan, and The Other Country, and further analyzes how in them the three main features of the then society under the charge of Lady Thatcher are reflected: moneymaking as the top notion of people, despair and aimlessness among the young generation, racial and cultural intolerance in the multicultural Britain.

\section{British Society in 1980s and 1990s}

After the two world wars, Britain was confronted with severe economic depression, stagnation in industry as well as mass unemployment among citizens. A welfare state was planned by the post-war 
governments with the goal of creating a state in which the central government plays an essential role in improving the economic and social well-being of its citizens. Based on "the principles of equality of opportunity, equitable distribution of wealth, and public responsibility" for those unable to avail themselves of the minimal provisions for a good life(Shi and Singh 112), its economic policy was targeted at creating jobs and avoiding unemployment, and a universal social security system is recommended to cover everyone in the country.

However, due to the serious economic position and the difficulties faced in the way, the Labor party's attempt to establish a welfare state failed. Accordingly, following the premiership of the Conservative Margaret Thatcher, what replaced it were the policies which almost went to the contrary. While the Labour policies were directed towards the "universality", the Conservative aimed at "selectivity" (Marwick 46). Under the policy of "universality" advocated by the former, the state service was planned to be open to all including the privileged as well as the deprived so as to assure equality in every sense of social life; whereas the latter proposed a luxurious private system catering to a small minority, yet rendering no benefit to the public service. The Labour party attached great importance to directing government intervention in economy, particularly through the nationalized industries with the goal of equal distribution of wealth; however, the Thatcher Governments aimed to build a free market undistorted by government intervention in which enterprise would thrive along with privatization of industries and of public housing, resulting in large numbers of the homeless and the unemployed.

When nationalization policy of the Welfare State was replaced with privatization, monetarism and free market economy introduced by the Thatcher government, an enormous quantity of problems emerged. The change towards privatization of economies resulted in the closure of coal mines and the steel mills which caused a dramatic unemployment and plunged the North of Britain into a bleak state of economic and social depression. Due to deindustrialization, the gap between "a prosperous and complacent South" and "a decaying, declining North with endemic unemployment, urban dereliction and collapsing public service" kept widening with "endemic unemployment, urban dereliction and collapsing public service" (Morgan 587).

The widening chasm between the South and the North, the rich and the poor, and deindustrialization within Britain were accompanied by internal conflicts during the 1980s when the Irish Trouble took place between Protestant Unionists and Catholic Independentists. Meanwhile, Britain gradually lost its prominence as a world power and the concept of "Englishness" was questioned, especially by ethnic minorities. Hooliganism, refering to unruly, destructive, aggressive and bullying behavior, particularly related to sport violence in Britain, was all the rage in the 1980s. And terms like "heritage industry" and "yuppies" popped out in this self-enterprise culture. As for this deregulated behavior among the young, what should be blamed ought to be the loss of commonly shared values, morals, ideologies and attitudes towards life as well as "the old reference points by which their behavior were constrained"(Marwick 351).

With the arrival of enormous number of immigrants, Britain has become a multicultural country. Meanwhile, "erosion of the post-war consensus and greater economic and social devision"(Kennedy 7) occurred in the society as a result of the economic policies of the 1980s and the "dissolution of the empire"(Aydin 7). As the problem of unemployment aggravated in 1980s and 1990s, immigrants, considered to give rise to the unemployment of native British and series of social problems, were seen as a big threat to British society. Since the 1950s, Britain faced floods of immigration from the former colonies, especially from the West Indies and Pakistan. At first, those immigrants were welcomed by the British government under the expanding economy's demand of extra workers to fill low-end labor needs. However, since 1960s, the entry of immigrants was restricted, especially in 1980s when Britain suffered high unemployment and racial violence from indigenous citizens. "Motivated to come to the mother country because of the poverty and unemployment back home and the attraction of a superior life and prosperity in Britain which was imposed on the colonized to rationalize the imperial domination"(Sinfield 143), immigrants swarmed into Britain from its former colonies. However, in contrast to their belief that they will find a "Christian country of love and tolerance, ready to welcome strangers and care for them" (Sinfield 126), immigrants, especially the black, faced discrimination and violence because of their cultural and racial differences. 
In the 1980s and the 1990s, under "the policies of polarization and confrontation pursued by the Thatcher Governmant"(Marwick 351), the British society has seen "the fostering of aggressive economic selfishness" and lack of concern for the less able and fortunate, and "despair and aimlessness among the country's youth". As a poet who deals with "a wide range of issues, from the effects of sexism, racism, immigration, domestic violence, and social disaffection, to the complexities of love"(Ree-Jones 1), Carol Ann Duffy presents to her readers a panoramic view of Thatcher's Britain.

\section{Reflection of the British Society in 1980s and 1990s}

In an interview with Andrew McAllister, Carol Ann Duffy stated that her poetry was "recording human experience" and "presenting it as it is" (McAllister 72). Focusing on life in the contemporary Britain, Carol Ann Duffy illustrates in her poetry "the social and political fabric of contemporary living" (Kennedy 228). The consumer society guided by policies like monetarism and privatization, where commercialization and individualism has become the major features of national culture, was depicted satirically in her poetry. Meanwhile, she speaks for the underprivileged, especially discriminated immigrants, and seeks to convey the sense of isolation, frustration and alienation experienced by them. I illustrate how Carol Ann Duffy's poetry reflects the British society in 1980s and 1990s in three aspects: moneymaking as the top notion of people, despair and aimlessness among the young generation, racial and cultural intolerance in the multicultural Britain.

Moneymaking as the Top Notion of People. Shifting from "the collectiveness of the welfare state" where collectiveness is stressed to "the laissez-faire of the 1980s and 1990s" emphasizing on individualism (Aydin 31), commercialism has gradually become a dominant feature of the then culture. In the contemporary Britain characterized by free market economy where everything becomes a commodity and money can buy anything you want, along with the widening gap between the rich and the poor, moneymaking has never been highlighted at a higher position. The poem "Money Talks" illustrates the decaying and corrupt atmosphere to the full.

I am the authentic language of suffering. My cold, gold eye

does not blink. Mister, you want nice time? No problem.

I say Screw you. I buy and sell the world. I got

Midas touch, turn bread to hard cash. My million tills

Sing through the night, my shining mad machines.

I stink and accumulate. Do you fancy me, lady? Really?

("Money Talks", Selling Manhattan, 1-6)

In this poem, Duffy launches a severe attack towards the contemporary British society where the spiritual is effaced by the material as moneymaking was placed as the top priority of life. "I am the authentic language of suffering. My cold, gold eye does not blink"(1), Money is personified and given a voice, demonstrating the affliction of those lack of money as well as the exploitation suffered in the seeking of it. In addition to the metaphorical voice of money, voices of people who crave it and take advantage of it are also heard. A prostitute who asked "Mister, you want nice time?" highlights the power of economic necessity along with the degrading humanity. In the last line of the first stanza, the whoremaster's voice appears. "Do you fancy me, lady? Really?" (2) The man, powerful and dominating as a possessor of wealth, begins to doubt the authenticity of the woman's affection towards him who possibly aims to make advantage of his wealth rather than love him.

See me pass through the eye of a needle! Whoopee,

I cut time dead with my sleek facelift. I travel

Faster than sound. Don't give me away; after all, no one

can eat me. Honey, I'm a jealous God, stammering

my one commandment on the calculator. Love me.

(7-11)

The second stanza contains three biblical illusions which reinforce the sarcasm towards those who superficially thirst for wealth. The first reference, "see me pass through the eye of a needle" (7), is "an allusion to Matthew 19:24 which asserts that 'it is easier for a camel to pass through the eye of a 
needle than for a rich man to enter heaven"'(Aydin 33). By contradicting this biblical statement, the voice of money claims to be able to do the impossible. Here, the low status attached to wealth by God is contrasted with the omnipotent power of it announced by humans. Besides, The "one commandment"(11) mentioned in line 11 ironically reduces the Ten Commandments to just one and this is associated with money, suggesting the opposite view commanded by God in the Bible, intensifying Duffy's satirical apprehension of those who are unable to see beyond the material.

The primacy of the American dollar is emphasized in the oral performance, "\$-sound" and " $\$$ stammering" and the typographical symbol. Here, in this poetry, the poet's critique of capitalism and the Conservative government of the 1980s could be clearly sensed. Duffy's other poems like "Making Money" (The Other Country 17) and "Translating the English"(TOC 11), also reveals and attacks the commodification and "the primacy of material wealth"(Aydin 33) prevalent in Thatcher's Britain.

Selfishness and Aimlessness Among the Young Generation. During the 1980s, under Thatcher government's policies like deindustrialization and privatization, a lot of social unrest took place in Britain: poll tax riots, the miner's strike, race riots in cities like Liverpool and Bristol. More seriously, the continual cuts in education, health and social services as well as the swelling unemployment rate plunge the country's young men into a state of despair and aimlessness. With the collapse of old references by which their behavior is measured, confused and not knowing what to do with themselves and the unintelligible world, the youth are frequently involved in anti-social behaviors in the 1980s, the typical of which is football hooliganism.

In several of her poems, Carol Ann Duffy reflects the difficult situation of young people, who tend to lead an aimless life while confronting high unemployment. In the poem "Job Creation", Duffy links the difficulty of employment to "the efforts of Liliputians to tie up the giant body of Gulliver" (Aydin 37) in Gulliver's Travel, sarcastically underlining the slump economic performance in the North and the trivial effort of government spent in creating jobs and avoiding unemployment.

In "Stealing"(SM 38), Duffy depicts a young man who commits the crime of theft. The speaker once steals a guitar he never played, a bust of Shakespeare and, most unusual of all, a snowman:

One time, I stole a guitar and thought I might

learn to play. I nicked a bust of Shakespeare once,

flogged it, but the snowman was strangest.

("Stealing", Selling Manhattan, 22-24)

The speaker steals things he doesn't need without any practical purpose, but merely to derive emotional satisfaction from it and enjoy the excitement or frisson of the act itself. His stealing of a snowman originates from a desire for companionship and intimacy, reflecting the psychological loneliness and alienation suffered by young people in the 1980s.
I wanted him, a mate
with a mind as cold as the slice of ice
within my own brain. I started with the head.
Better off dead than giving in, not taking
what you want. He weighed a ton; his torso,
frozen stiff, hugged to my chest, a fierce chill
piercing my gut. Part of the thrill was knowing
that children would cry in the morning. Life's tough.
Sometimes I steal things I don't need.

"Part of the thrill was knowing that children would cry in the morning"(10), the pleasure of stealing resides not only in the act itself, but strengthens in others' misery and suffering, like the irritating reaction of children when they found the snowman is gone. "Better off dead than giving in, not taking"(6), selfishness and self-interest is underlined in the 1980s, under the premiership of Lady Thatcher glutted with individualism and greed. When the speaker failed to reassemble the snowman, his despair and hopelessness are highlighted through the violent act of booting the snowman. The boredom and futility of life devour him again. In spite of attempting to disperse the sense of boredom and futility through learning to play a guitar, the narrator is "sick of the world" and "so bored I could eat [him]self'(20-21), The speaker's image is a profile of young people in 1980s, leading a boring and 
aimless life punctuated only by random acts of vandalism, theft and cruelty, who entertain at other's expense and misery.

Racial and Cultural Intolerance in the Multicultural Britain. Poetry in the 1980s and 1990s was characterized by a plurality of voices, highlighting "the beginning of the end of British poetry's tribal divisions and isolation", and promotes "the inclusion of different cultural and ethnic voices" in poetry (qted Aydin 1). Revealing and presenting Britain as a country characterized by diversity and disintegration, Carol Ann Duffy's poetry gives voices to "those traditionally on the periphery" (qted Aydin 1) and reflects displacement and discrimination suffered by immigrants in the multicultural Britain. In the poem "Comprehensive" (Standing Female Nude 8), we are presented with the situation of ethnic minorities in Britain.

The poem explores the attitudes, hopes and fears of both indigenous English and immigrant pupils. The whole poem consists of seven stanzas, giving voice to seven teenagers of various origins, three of whom are white while four from ethnic minorities. Originally, comprehensive education is predicated on the idea of equality of opportunity irrespective of gender, intelligence, wealth, race or religion. However, in the comprehensive school depicted in the poem, disparity exists among the speakers and disjointedness and disintegration are found in the society in which they live in.

Tutumantu is like hopscotch, Kwani-kwani is like hide-and-seek

When my sister came back to Africa she could only speak

English. Sometimes we fought in the bed because she didn't know

what I was saying. I like Africa better than England.

My mother says You will like it when we get our own house.

We talk a lot about the things we used to do

in Africa and then we are happy.

The first stanza is written in the voice of a young African child who naturally tries to familiarize her/himself into the English culture by comparing it with her own: "Tutumantu is like hopscotch, Kwani-kwani is like hide-and-seek. (1)" In spite of the different cultural background, the phrase "is like"(1) tries to strike us by "a perception of similarity within difference"(qted Aydin 45). Complication is presented later, however, in the conflict between sisters, one of who has returned on a visit to Africa after being immersed in English culture for some time. The language barrier posed as the source of conflict between siblings further suggests the potential disparity between immigrants and the native resulted from linguistic difference. The boy depicted in the last stanza suffers from the same problem: unable to understand English, the consequence of which is the deprivation of milk in school with a clear implication that this will be extended to other areas of life beyond it.

Wayne. Fourteen. Games are for kids. I support

the National Front. Paki-bashing and pulling girls'

knickers down. Dad's got a mini-cab. We watch

the radio. I Spit on Your Grave. Brilliant.

I don't suppose I'll get a job. It's all them

Coming over here to work. Arsenal.

In the second stanza, Duffy reveals through a racist boy the ironic tension between the idealized inclusiveness of a comprehensive school and the exclusivity, racism and prejudice of the indigenous English pupils in reality. The second speaker is a fourteen-year-old English teenager called Wayne who follows the National Front, an unashamedly British racist organization advocating white supremacy. Entertained in "Paki-bashing and pulling girls' knickers down" (9), organized attack of Indian immigrants and sexual terrorization of young women, the boy's racist tendency is clearly demonstrated. He holds a negative attitude towards employment like the English girl in the fourth stanza who bears a humble job expectancy, and blames unemployment on immigrants. He is also a racist football fan and his "racism" is seen by the poet as institutionalized rather than deriving from his own perception. Like the English girl, who has been honesty about her attraction towards a black boy but unable to cross the cultural boundaries because of his "a bit dark" complexion, the boy's inherited discrimination towards non-white reflects the profound internalized racism in indigenous English. 
The next student is a Muslim teenager, who pines for the cultural and religious patterns with which she is familiar and the country where there is "the friendly shop selling rice" (15) and where "Families face Mecca"(16). A sense of pathos generates through Duffy's use of the past tense, which is accentuated in the final sentence, "People wrote to us that everything was easy here"(20), juxtaposing the cruel reality with the dreamlike assumption. The girl's home village is now "empty" because of the economic attractions of England. Britain, as the mother country of the empire, is deemed to be of better conditions after the dissolution of the Empire, and an enormous number of immigrants from the previous colonies attempt to seek a work in the former motherland with the aim of getting rid of poverty. However, out of their braw expectation, they find Britain a country permeated by discrimination and intolerance.

Cultural and religious diversity is explored further in following stanzas. Ejaz, a Pakistani boy, is warned by a Muslim against pork, forbidden by those practicing this religion. Their shared language and religions lay the foundation for their solidarity and friendship. The sixth speaker, an English boy who might be capable of establishing friendship with Sikhs whose turbans mark them out as being "different from us"(34), but fails resulting from the cultural and ethnic differences. Ironically, the English boy plans to immigrate to Australia when he gets married, suggesting that Britain, burdened with economic recession and striking unemployment, was no longer a country of hope once yearned for by people from colonies but instead becomes a place where even the natives want to escape.

In the multicultural society in the 1980s and the 1990s, immigrants from various cultures and of different races still be perceived in the perception of "immigrant" by the native citizens, discriminated by and unassimilated into the central and dominant culture and deemed to.

\section{Conclusion}

As Aydin says, Duffy's poetry shows "particular responsiveness to the society she lives in" (Aydin 18). "Motivated, in part, by her own experiences of marginality as both lesbian and Scottish"(Kinnahan 209), Duffy tends to give voice to the marginalized and alienated people in her poetry. And as a female poet culturally and politically shaped in Thatcher's Britain, Duffy reflects in her poetry main features of the Britain in the 1980s and 1990s involving self-interest and greed of people, youth anomie, racial and cultural tensions in the multicultural country.

\section{Reference}

[1] Duffy, Carol Ann. Standing Female Nude. London: Avil Press Poetry, 1985.

[2] Selling Manhattan. London: Avil Press Poetry, 1987.

[3] The Other Country. London: Avil Press Poetry, 1990.

[4] Goulbourne, Harry. Ethnicity and Nationalism in Post-Imperial Britain. Cambridge: Cambridge UP, 1991.

[5] Kennedy, David. New Relations: The Refashioning of British Poetry, 1980-1994. Bridgend: Seren, 1996.

[6] Kinnahan, Linda. " 'Now I am Alien' : Immigration and the Discourse of Nation in the Poetry of Carol Ann Duffy." Contemporary Women's Poetry: Reading/Writing/Practice. Eds. Mark Allison and Deryn Rees-Jones. London: MacMillan, 2000. 208-225.

[7] McAllister, Andrew. "Carol Ann Duffy Interview.” Bete Noir 6(1988):69-77.

[8] Marwick, Arthur, British Society Since 1945. London: Penguin Books, 1982.

[9] Morgan, Kenneth O.ed. The Illustrated History of Britain. Oxford: Oxford UP, 1996.

[10] Rees-Jones, Deryn, Carol Ann Duffy. Devon: Northcote, 1999. 